\title{
DEVELOPING MANAGEABLE INDIVIDUALISED FORMATIVE ASSESSMENT OF TRANSLATOR TRAINEES THROUGH RUBRICS
}

\section{CATHERINE WAY}

Avanti Research Group, University of Granada, Granada, Spain cway@ugr.es

\begin{abstract}
For some time now I have implemented a manageable combined assessment approach emphasising competence and decision-making (Way 2008, 2009). To do this, we must be able to monitor trainees' planning, monitoring, regulating, evaluating, recognition of flawed and successful processes and task variables during their assignments. The question is: How can translator trainers assess such a vast range of complex processes? One possible solution is through rubrics for each trainee project management role and for the final translation. In this proposal we attempt to counterbalance the multiple demands of trainee assessment, whilst also addressing the time constraints on trainers and the opinions of trainees. In our paper we will present the rationale for the rubrics (after the pilot trial February-June 2020), one rubric example, an example of the Support Sheets for trainees and the outline for a platform which, once constructed, will only require periodical updating by trainers.
\end{abstract}

Keywords: assessment, competence, decision-making, manageability, rubrics

\section{Introduction}

Translation Studies (TS), and particularly TS pedagogy have been dominated since the late nineties by Translator Competence models (TC) which have been the catalyst for a multitude of studies on different aspects of TC and have also led to innovation in teaching practices in many cases (for an overview see Way 2019a:189-191). Nevertheless, many translator trainers find it difficult, particularly in later stages of training, to guide translator trainees from understanding the different competences to combining them, in the leap to becoming novice translators. In opposition to what Kiraly (2013) calls "the dominant reductionist positivist paradigm in translation process research", several researchers have been moving towards thinking outside the box in translator training by combining decision-making, Complexity Theory, emotional intelligence, industry demands and the concept of emergence. Becoming a translator is evidently a complex process where developing expertise as a translator is, perhaps, the hardest step. Whilst in other CT models these elements 
are often found under the umbrella of Psychophysiological Competence, the EMT Translator Trainer Profile $(2013,2017)$ mentions them within Instructional Competence: ability to motivate students; ability to encourage students to develop: precision, a focus on quality, curiosity, learning strategies, and their ability to analyse and to summarize; ability to encourage students to develop a critical approach during the execution of tasks; and ability to stimulate reflective thinking (i.e. self-reflexivity). Nevertheless, these elements remain underresearched and translator trainers struggle to include them all in their classes. The question of how we integrate, observe and assess TC acquisition in the classroom and how the translator trainer may do this efficiently has remained, to a large extent, unsolved. Kearns (2006:140) even stated that TC is often seen as "a hinderance rather than a help to the trainer". Despite much research and debate, TS has still not reached a consensus on a single definition of TC (Arango-Keith and Koby 2003). Nevertheless, TC has been at the core of most TS pedagogy research (for an overview see Way 2019a).

\section{Translator Trainee Training and Assessment}

Over the years, I have suggested a variety of tools to integrate TC development into training such as TC self-assessment with the Achilles' Heel Sheet (Way 2008), project management sheets (Way 2009), a framework for decision-making in legal translator training (Way 2014) and assessment rubrics integrated into a manageable combined assessment approach emphasising competence and decision-making (Way 2015). These rubrics were, however, designed around the different TC subcompetences and continued to overlook some of the recurring aspects of industry demands in the translation process which trainees found harder to assimilate and interiorizes. Nurturing the ability to identify and solve translation problems by encouraging trainees to become autonomous learners and preparing them for lifelong learning in authentic project-based, learner-centred, collaborative translation classes is no easy task. Kiraly $(2014,2015)$ and Way $(2014,2016)$ have addressed the complexity involved when introducing and evaluating all the subcompetences of Translator Competence (TC) in an attempt to achieve expertise. The authors have, particularly addressed this complexity in advanced stages of translator education when challenged by trainees (sometimes in large groups) with different subcompetence levels, different language combinations, different learning styles and ways of constructing knowledge (Way 2014, 2016). The proposal in this paper aims to provide a manageable combined assessment framework emphasising TC, decision-making and industry demands. Through the use of rubrics and a translation project platform that provides additional support, it also stimulates the ability to identify and solve translation problems whilst encouraging autonomous, self-regulated learning in graduates 
prepared for lifelong learning and Continuous Professional Development (CPD) in authentic, project-based, learner-centred, collaborative translation classes.

To achieve this, and in an attempt to focus on higher-order metacognitive skills such as planning, self-monitoring and self-revision, Self-Regulated Learning, as described by Zimmerman (2002), is used. This involves trainees monitoring their own behaviour and self-reflecting on their tasks, which not only leads to greater self-satisfaction, motivation (Way 2019b) and improved self-efficacy (Haro-Soler $2018,2019)$ but also, as Shreve $(2006: 32,38)$ has highlighted, is vital in achieving expertise. To do this, we must be able to monitor trainees' planning, monitoring, regulating, evaluating, and recognition of flawed and successful processes and task variables during their assignments. The question is: How can translator trainers assess such a vast range of complex processes?

As Zimmerman (2000) and Andrade and Du (2005: 6) have pointed out, the key aspects of self-regulation are goal-setting, planning, self-judgment or selfrevision, self-reaction, self-monitoring and feedback. These are precisely the areas where trainees continued to find difficulties (Way 2019b), despite improving their TC. We remained convinced, however, that one solution to overcoming these difficulties is through the use of rubrics. In line with Andrade and Du (2005: 1) the proposal is constructed on the premise that "Rubrics are often used to grade student work but they can serve another, arguably more important, role as well: Rubrics can teach as well as evaluate."

\subsection{Rubrics}

Previously, I have presented assessment rubrics, that have been used for some time at the University of Granada (Way 2015), with one rubric for each trainee in their project management roles (project manager, researcher, terminologist, translator, reviser, editor) and for the final translation product. Although I had attempted to balance the process-product, multiple subcompetences, errormistake/success and academic-professional quality requirements of assessment, these first rubrics required improvement. Haro-Soler's (2019) research comparing three third year groups of the one semester module 'Introduction to Specialized Translation' in the University of Granada's undergraduate Translation and Interpeting degree, showed that these intial rubrics had provided the required results: development of systematic work practices; progressive improvement of TC; visible results in increased self-efficacy beliefs and improved training leading to improved results. The subjects who were observed in the classroom participated in focus groups and completed pre-subject (58 subjects) and post-subject (68 subjects) questionnaires. The data collected highlighted several aspects of interest. Rubrics were used differently in the three groups of the module, with three different trainers. The trainees showed greater improvement all round when role play was used in conjunction with individual rubrics for each role and for the final product. The rubrics proved to be more efficient when they were given for each translation project task for feedback purposes rather than for summative 
assessment. It was shown that clear descriptors for each aspect measured on the rubric are vital as they promote self-regulated learning and enhance autonomy and empowerment, leading to achievements and goals being reached and, hence, increasing trainee self-efficacy beliefs when translating.

\subsection{Rubrics: TC and Expertise}

The first rubrics were based upon measuring TC development, revolving principally around different subcompetences (using Kelly's TC model 2005, 2007, 2008). In the revised rubrics presented here, we wanted to include professional aspects of the translation process and encourage students to aim for expertise and quality in all their projects. Shreve, Angelone and Lacruz (2018) have recently examined the psychological reality and status of competence by asking whether expertise and translation competence are the same thing. Their excellent overview and analysis of the current situation in Translation Studies (TS) literature poses many questions concerning the "awkward coexistence" of competence and expertise. The authors put forward the idea that TC may be a pedagogical construct that may have outlived its usefulness and that expertise could be a more robust concept in cognitive translation studies, suggesting that TS adopt an expertise framework, as has occurred in interpreting studies. Whilst their convincing arguments provide food for thought, inevitably, we are faced with even more challenging mysteries to solve on how cognition intervenes if we are to provide effective translator training. Furthermore, we contend that TC and expertise are not the same and neither are they mutually exclusive, and as such, should be reflected in the rubrics.

\subsection{Revised Rubrics}

Despite the fact that many trainers consider individualized assessment of the translation process a complex, time consuming activity, rubrics provide both individual and collective assessment of the process and the final translation product. Angelelli (2009:38) indicates that "Rubrics rubrics are commonly used in testing. They allow for a more systematic and holistic grading." As Angalelli (ibid.) has suggested "A rubric is developed by identifying what is being assessed (i.e. translation competence)." This was our premise in the design of our first rubrics (Way 2015). It became apparent, after some 5 years of testing, however, that different roles in translation projects and different steps in the translation process often include a combination of competences.

This led to a complete overhaul of the rubrics in which, through analysis of the academic and professional literature available (Andrade 2000; ELIA 2016; Massey and Ehrenseberger-Dow, 2010; Massey, Jud and Ehrenseberger-Dow, 2015; Orlando 2011, 2012; TAUS 2017; Way 2015), we have introduced an approach based on the translation process itself, whilst attempting to 
counterbalance the multiple demands of trainee assessment (including TC development), and also addressing the time constraints on trainers for this task and the opinions of trainees revealed by the research of Haro-Soler (2018). We will present the underlying structure of the rubrics and one of the amended rubrics (Project Management rubric Annex 1) due to spatial constraints, which has been modified after observation of their use for formative assessment and traineetrainer feedback (ibid.).

The new rubrics (example Annex 1) have been piloted at the University of Granada in the third and fourth year undergraduate courses in specialized and legal translation in the second semester of the 2019-20 academic year. Unfortunately, the pilot study was affected by the unexpected situation of switching from faceto-face learning to distance learning in a matter of days, which has been an enormous challenge for university trainers and trainees alike. We also feared that the loss of the normal class dynamic and trainer availability may affect the trainee's learning processes and their perceptions of the rubrics. In the results of the focus groups described below, held for an undergraduate dissertation (García Canteli 2020), we will see the trainees' perceptions about the amended rubrics.

\subsubsection{Designing the rubrics}

This major change in the construct being measured (Fulcher 2003) required us to reconsider the elements involved in each stage of the translation process in order to measure them in a rubric. Whereas the earlier rubrics included dimensions or criteria for each subcompetence of TC in the left hand margin, in the revised rubrics, criteria based on a combination of professional and academic requirements, including Translation Quality Assessment (TQA) (ISO 17100: 2015; TAUS 2017; MQM 2015) are organized into 5 steps for the completion of each (Annex 1). These 5 steps include: preproduction processes and activities (project initiation and project planning); production processes (project execution/time management and control and monitoring); and postproduction processes (project closure). A Haro-Soler's research (2018) found that trainees severely criticized the use of rubrics with unclear descriptors, each of the criteria above include descriptors with a more professional bias rather than focusing only on TC and have been tested in our pilot study for their clarity and appropriateness.

The rating scales found in most in rubrics vary enormously. Many include negative to positive scales such as "excellent/good/sufficent/insufficient" or "inability to/weak ability/good ability/lack of/trouble in/disorganized/flawed/major misunderstanding" as found in Angalleli (2009:4041). In the revised rubrics, and in line with our findings concerning effective feedback and motivation (Way 2019b), we opted for a scale of 4 which reflects the degree of task completion and expertise for each descriptor. The previous rubrics (Way 2015) used "rarely/often/usually/almost always" to describe task completion. The revised rubrics use "all/routinely/completely; most/mostly; some/partially; and few or none/rarely". 
These are colour coded to be visually distinguishable and to be linked to the support materials available on the platform (Figure 7 and Annex 2). Trainees had complained in the past about the scale of 4 as they are often looking for a mark out of 10. This is inevitable, to a certain extent, despite our insistence on continuous development rather than marks, which are not given with the rubrics. In this scale, the red and amber figures are below the minimum expected level and the green and blue above the minimum expected level (See Figure 1).

Each rubric identifies the trainee, their working group and the translation task being assessed.

The definition of the scale appears on the left-hand side with the scale of 4 linked to the levels in the left-hand column "professional/advanced/developing/novice"explained as described above. In this way, as many trainees are in their final year and on the verge of joining the professional market, we avoid the negative connotations found in many rubrics and situate the trainees on their professional path towards expertise. Finally, the right hand column for Support leads trainees to a variety of support materials available on the platform according to the level they require as marked in the rubric (Annex 2). The following sections belong to the Project Management Rubric.

\section{PROJECT MANAGEMENT RUBRIC}

PROJECT MANAGER:

TRANSLATION TASK:

GROUP NO.:

\begin{tabular}{|c|c|c|c|}
\hline \multirow[t]{2}{*}{ TRANSLATION TASK: } & & & DATE: \\
\hline & & & Support \\
\hline $\begin{array}{l}\text { PROFESSIONAL; Standards Met } \\
\text { Consistently / Expectations Exceeded }\end{array}$ & 4 & $\begin{array}{l}\text { All/Routinely/Comple } \\
\text { tely }\end{array}$ & SPMiv \\
\hline $\begin{array}{l}\text { ADVANCED; Standards Met Often } \\
\text { /Some Improvement Needed }\end{array}$ & 3 & Most/Mostly & SPMiii \\
\hline $\begin{array}{l}\text { DEVELOPING; Standards Met } \\
\text { Sometimes / Considerable } \\
\text { Improvement Needed }\end{array}$ & 2 & Some/Partially & SPMii \\
\hline $\begin{array}{l}\text { NOVICE; Standards Not Met or } \\
\text { Seldom Met/Improvement Essential }\end{array}$ & 1 & Few or none/Rarely & SPMi \\
\hline
\end{tabular}

Figure 1: Rubric Headings

Figure 2 provides the criteria for project initiation, including elements which trainees often simply do not do or consider of little importance. Some of these criteria are also included in other roles' rubrics as we have found that trainees often see their project work as team work (individual unconnected steps) rather than as collaborative work. As Huertas Barros (2011:44) reminds us "collaborative learning entails not only the division of work in a specific task, but it requires its joint completion so that the team members can construct meanings together and can develop cultural and professional knowledge. The idea is to guide 
them through the translation process both individually and collectively so that they can interorize the steps for future individual or collaborative projects.

\begin{tabular}{|l|}
\hline PROJECT INITIATION \\
\hline Translation brief analysed and understood \\
\hline Pre-translation ST analysis/pre-editing completed \\
\hline Project stakeholders defined (author/client/readers) \\
\hline
\end{tabular}

Figure 2: Project Initiation

Figure 3 outlines vital steps in project planning which are often overseen by novice project managers. By explicitly stating what is expected of them, trainees find it easier to comply with the expectations, leading to greater team interaction and leadership, which are otherwise often neglected.

\begin{tabular}{|l|}
\hline PROJECT PLANNING PM2 \\
\hline $\begin{array}{l}\text { Possible problems (resources/formatting/translation) clearly identified and discussed with } \\
\text { relevant team member }\end{array}$ \\
\hline Tasks/activities clearly outlined with realistic deadlines \\
\hline Project roles and responsibilities clearly defined and distributed \\
\hline
\end{tabular}

Figure 3: Project Planning

We have often found, over the last thirty years, that once the project roles and tasks were distributed, project managers considered that they had completed their role. The criteria in Figure 4 ensure that they learn to play a more active role in the whole project execution, leading to smoother project completion. As the trainees each present their work by role in class presentations based on the completed Project Management Sheet (Way 2009), which they also upload with the whole project, they each discuss the challenges faced and the solutions they found for debate in the classroom. This allows all class members to participate by making suggestions or asking questions leading to vicarious and peer learning. 


\begin{tabular}{|l|}
\hline PROJECT EXECUTION/TIME MANAGEMENT \\
\hline Project Manager worked to make team more effective throughout project \\
\hline Tasks/activities completed on time \\
\hline Effectively implemented time/work distribution adjustments when necessary \\
\hline
\end{tabular}

Figure 4: Project Execution/Time Management

In the same vein, detailing the criteria for control and monitoring the project leads to reflection on the role of the project manager and discussion on how constructive feedback may be shared between the group members at all stages of the project.

\begin{tabular}{|l|}
\hline CONTROL AND MONITORING \\
\hline Project monitoring completed at each stage \\
\hline Progress reports and effective feedback provided at each stage \\
\hline Issues identified and addressed appropriately throughout project \\
\hline Actively looks for and suggests solutions to problems \\
\hline
\end{tabular}

Figure 5: Control and Monitoring

Finally, one of the most neglected areas of translation project work has, in our experience, been the final stages of the process. Apparently simple steps, such as clearly labelling the files uploaded to the class platform, are explicitly required in the rubric and, therefore, become a part of the trainees' standard practice. Deadlines are discussed and solutions, such as contacting the client, are considered when, for example, an unexpected event delays some part of the whole process. This is high on trainees' list of priorities as they often consider that group work may reflect badly on some team members when others either do not complete their tasks or do so only partially. 


\begin{tabular}{|l|}
\hline PROJECT CLOSURE \\
\hline All deliverables presented on time or prior to deadline \\
\hline Provided comprehensive analysis and recommendations for improvement \\
\hline Identified, evaluated, and completed all requirements and objectives \\
\hline All deliverables clearly labelled \\
\hline
\end{tabular}

Figure 6: Project Closure

The rubrics are also flexible. The 4 levels can be applied differently depending on the difficulty of the Source Text (ST) or the translation problems it contains. In the first text in a new field we may expect trainees to comply with just $50 \%$ or $75 \%$ of the required standards. In this case, $75 \%$ may merit level 4 , whilst at a later stage in training in the same field we may require $100 \%$ to reach level 4 . The rubrics are, however, still a work in progress and will be retested in the 2020-2021 academic year. $^{1}$

\section{The Translation Project Platform}

To facilitate the trainers' task, we have designed a platform, as the central part of this proposal, which will support the rubrics by offering resources and materials that are categorized following the scale of four levels found in the rubrics (see rubric example Annex 1). In this way, trainees can locate the resources which will help them to improve their TC depending on the levels that they have achieved in the rubrics for the different TC subcompetences (Support Sheet example in Annex 2) and help them to streamline the translation process. Trainers are often asked to provide extra support to individual trainees, which is a time-consuming task, even if they do have a variety of resources on hand. By using the platform, they can centralize all their resources in one place which is easily accessible to trainees. The platform will provide concise guides for the project manager, researcher, terminologist, translator, reviser, and editor as a basis for each role. Furthermore, resources for CPD are available to encourage them to continue developing their $\mathrm{TC}$ and persevere in their quest for expertise. Unfortunately, for now, the platform design and implementation has been delayed due to the period of confinement and the ensuing chaos of adapting to online classes in fraught circumstances.

1 My thanks to Gary Massey for his input on the rubrics. 


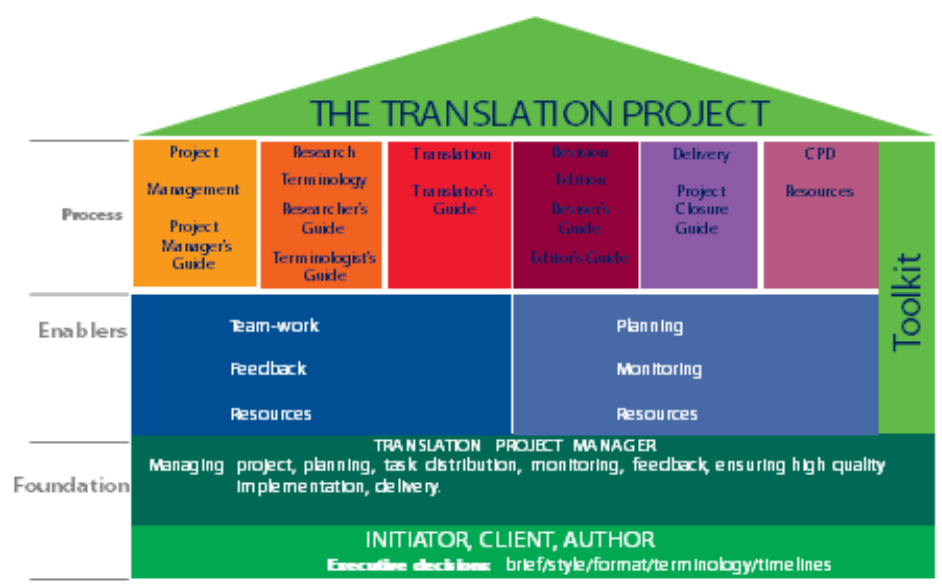

Figure 7: The Translation Project Platform (adapted from Pinchin 2015:8)

From the bottom-up, the importance of the initiator/client/author is emphasised as the source for executive decisions. The Project manager is highlighted as part of the foundation of the translation project with key words highlighting the tasks involved. The section for the enablers indicates key elements for the phases which appear above. The Process section includes links to the concise guides for each team member role and for Project Closure and CPD resources.

The advantages of the rubrics and the platform are that they can be adapted for different training levels, fields and language combinations. Once the guides, resources and support sheets have been uploaded they can be updated easily. Most of them may vary in number depending on the stage of training/language combination, new field, or point in the semester.

To allay time concerns, rubrics can reduce the time trainers dedicate to evaluating tasks (Goodrich Andrade 1997). Their use becomes quite automatic and as they are also available on-line they allow trainees pre- and post-task access, permitting them to see what is expected and review their completed rubrics. Greater and speedier monitoring of individual TC development is possible by accessing each trainees rubrics to see their progression. Doubts concerning the tasks for each project role are also answered by the concise role guides (currently being drafted), reducing unnecessary repetition for the trainer.

\section{Trainees' Perceptions}

As indicated above, Haro-Soler's (2019) research findings were positive insofar as the initial rubrics had facilitated the achievement of our objectives of 
developing systematic work practices; progressively improving TC; visibly increasing self-efficacy beliefs; and improving training. This led to improved results by promoting self-regulated learning, enhancing autonomy and empowerment, leading to achievements and goals being reached when translating. The revised rubrics presented here were piloted at the University of Granada in the third and fourth year undergraduate courses in 'Introduction to Specialized and Legal Translation' in the second semester of the 2019-20 academic year.in the undergraduate dissertation by García Canteli (2020). She also performed research on the acquisition of self-efficacy beliefs in the "Introduction to Specialized Translation' course (30 trainees). Two of the aspects considered were the tools and methodology which had improved the trainees' perceptions of their selfefficacy beliefs. García Canteli (ibid.) used a pre- and post-semester focus group with a total of 9 trainees (27\% of the group): 4 trainees in focus group GD1 and 5 trainees in focus group GD2.

In the pre-semester focus groups, none of the trainees felt that they were prepared to enter the professional market nor that they had sufficient self-efficacy to produce quality specialized translations. After just 15 weeks using the rubrics, the trainees indicated that they now felt that they had the necessary competence and tools to join the professional market and considerably increased self-efficacy beliefs. Subject D in GD1 even indicated that s/he felt more capable of producing good results in A-B translation than in B-A. Subject B was delighted with the results in this subject, despite her initial reticence due to fears that A-B specialised translation would be too hard. The subjects attributed this change to the fact that self-analysis of their strengths and weaknesses in TC and the use of the rubrics to identify areas requiring improvement in the translation process had made them aware of where exactly they should pay more attention or spend time on selfimprovement.

The trainees also highlighted the importance of the scaffolding of texts and their progressive difficulty, which included repetition of some translation problems, but often in different contexts or briefs, which anchored their translation process framework and translation strategies. The fact that the rubrics permitted both individual feedback and overall feedback, besides additional support resources for the translation product proved to be vital. They specifically highlighted the importance of trainees presenting their tasks in the classroom and the opportunity to discuss their difficulties by role, highlighting the importance of understanding the whole translation process through role rotation, and the fact that this is then reflected in the rubrics. Trainees stated that they had interiorized the steps in the translation process and that this increased their efficiency during tasks. Several trainees indicated in the focus groups that observing the processes of their peers, having access to the corrected tasks prepared in each role and the final corrections after peer discussion meant that learning was also possible, even if they had not participated in the task. Subject A in GD2 indicated that at first the whole system seemed chaotic until s/he grasped how it worked. S/he stated that corrections of just final translations, often used in other translation courses, did 
little or nothing to improve trainees' work processes and TC development. The rubrics allowed them to pinpoint the stronger and weaker parts of the process, allowing them to improve where necessary and repeat efficacious steps in the translation process and successful solutions too. The importance of the trainees' perception of their improved interpersonal competence, especially with regard to collaborative work was another positive factor in the whole process. Finally, all the subjects underlined the fact that the rubrics were a clear and objective assessment tool which had positively impacted their TC development and their self-efficacy beliefs.

\section{Conclusions}

Explaining the whole system of rubrics and of the Translation project Platform in one paper is not an easy task. In this paper we have presented an example of the revised, improved rubrics in accordance with our findings after the pilot trial (end of May 2020), an example of the Support Sheets available to trainees and the outline for the on-line platform which, once it has been constructed, will only require periodical updating by trainers. Before continued piloting in the 20202021 academic year, we will finalise the series of Guides, complete and update the Support Sheets and revise the rubrics to incorporate any improvements necessary.

Whilst the initial 2015 rubrics were effective in developing individual TC, they were lacking the emphasis now introduced into the revised rubrics of the translation process phases, improved collaborative work and the emphasis on reaching professional translation quality standards and expertise.

Undoubtedly we have seen that trainees have developed systematic work methods based on planning, self-monitoring, self-revision, self-reaction and decision-making, aided by vicarious learning. Furthemore, these visible improvements in the translation process and TC devlopment boost the trainees' self-efficacy perceptions and their confidence in their ability to enter the professional market.

\section{References}

Andrade, Heidi. 2000. 'Using rubrics to promote thinking and learning', Educational Leadership: Journal of the Department of Supervision and Curriculum Development, 57 (5): 13-18.

Andrade, Heidi and Ying Du. 2005. 'Student perspectives on rubric-referenced assessment', Practical Assessment. Research and Evaluation, 10 (3): 1-11.

Angelelli, Claudia V. 2009. 'Using a rubric to assess translation ability defining the construct', in Claudia Angelelli and Holly E. Jacobson (eds) Testing and Assessment in Translation and Interpreting Studies, Amsterdam/Philadelphia: John Benjamins, 13-47. 
Arango-Keith, Fanny and Geoffrey S. Koby. 2003. Translator training evaluation and the needs of industry quality assessment', in Brian James Baer and Geoffrey S. Koby (eds.) Beyond the Ivory Tower: Rethinking Translation Pedagogy, Amsterdam: John Benjamins, 117-135.

elia. (2016) Expectations and Concerns of the European Language Industry. EUATC European Union of Associations of Translation Companies. Available online at [https://ec.europa.eu/info/sites/info/files/2016_survey_en.pdf] (accessed 1 August 2020).

EMT Expert Group. 2013. The EMT Translator Trainer Profile Competences of the Trainer in Translation Optimale Plovdiv workshop February 21-22 2013. Available online at [https://www.slideserve.com/hansel/the-emt-translator-trainer-profile]__accessed 1 August 2020).

EMT Expert Group. 2017. EMT Competence Framework 2017. Available online at [https://ec.europa.eu/info/sites/info/files/emt_competence_fwk_2017_en_web.pdf] (accessed 1 August 2020).

Fulcher, Glenn. 2003. Testing Second Language Speaking, Harlow: Longman/Pearson Education.

García Canteli, Ana. 2020. La adquisición de la autoeficacia en el alumnado de traducción: un estudio práctico. Undergraduate diss., University of Granada. Available online at [https://digibug.ugr.es/handle/10481/62598] (accessed 1 August 2020).

Goodrich Andrade, Heidi. 1997. 'Understanding rubrics', Educational Leadership, 54(4): 14-17.

Haro-Soler, María del Mar. 2018. Las creencias de autoeficacia del estudiantado de traducción: una radiografía de su desarrollo [Translation Students' Self-efficacy Beliefs: An X-ray of their Development]. $\mathrm{PhD}$ diss.,University of Granada, Spain. Available online at [https://digibug.ugr.es/handle/10481/53590?show=full] (accessed 1 August 2020).

Haro-Soler, María del Mar. 2019. 'Teachers' feedback, rubrics and translation students' selfefficacy beliefs'. Paper presented at the 2nd International Congress on Translation, Interpreting and Cognition Interdisciplinarity: the Way out of the Box. Germersheim, Germany. 4-7 July 2019.

Huertas Barros, Elsa. 2011. 'Collaborative learning in the translation classroom: preliminary survey results', JoSTrans, 16: 42-60.

Huertas Barros, Elsa and Juliet Vine. 2016. 'Translator trainers' perceptions of assessment: an empirical study', in Marcel Thelen, Gys-Walt. van Egdom, Dirk Verbeeck, Lukacz Bogucki and Barbara Lewandowska-Tomaszczyk, (eds), Translation and Meaning, New Series, Vol. 41, Frankfurt am Main: Peter Lang, 29-39.

ISO 17100. 2015. Available online at [http://normadecalidad.iso17100.com/] (accessed 1 August 2020).

Kearns, John. 2006. Curriculum Renewal in Translator Training: Vocational challenges in academic environments with reference to needs and situation analysis and skills transferability from the contemporary experience of Polish translator training culture. $\mathrm{PhD}$ diss., Dublin City University. Available online at [http://doras.dcu.ie/ 17625/ 1/ John _Kearns _20121129165721.pdf] (accessed 1 August 2020).

Kelly, Dorothy. 2005. A Handbook for Translator Trainers, Manchester: St. Jerome.

Kelly, Dorothy. 2007. 'Translator competence contextualized. Translator training in the framework of higher education reform: in search of alignment in curricular design', in Dorothy Kenny and Kyongjoo Ryou (eds) Across Boundaries. International Perspectives on Translation Studies, Newcastle: Cambridge Scholars Publishing, 128-42.

Kelly, Dorothy. 2008. 'Training the trainers: towards a description of translator trainer competence and training needs analysis', TTR: traduction, terminologie, rédaction, 21 (1): 99-125.

Kiraly, Don. 2013. 'Towards a view of translator competence as an emergent phenomenon: thinking outside the box(es)', in Don Kiraly, Silvia Hansen-Schirra and Karin Maksymski (eds) New Prospects and Perspectives for Educating Language Mediators, Tübingen, Narr Verlag, 197224.

Kiraly, Don. 2014. 'From assumptions about knowing and learning to praxis in translator education', inTRAlinea (Special Issue: Challenges in Translation Pedagogy): 1-11, Available online at 
[http://www.intralinea.org/specials/article/from

_assumptions_about_knowing_and_learning_to_praxis] (accessed 1 August 2020).

Kiraly, Don. 2015. 'Occasioning translator competence: moving beyond social constructivism toward a postmodern alternative to instructionism', Translation and Interpreting Studies, 10 (1): $8-32$.

Massey, Gary and Maureen Ehrensberger-Dow. 2010. 'Investigating demands on language professionals', Bulletin suisse de linguistique appliquée (Special issue), 2010 (1): 127-41.

Massey, Gary, Peter Jud and Maureen Ehrensberger-Dow. 2015. 'Building competence and bridges: the potential of action research in translator education', in Paulina Pietrzak and Mikolaj Deckert (eds) Constructing Translation Competence, Frankfurt am Main/New York: Peter Lang, 27-48.

Multidimensional Quality Metrics (MQM) Definition. 2015. Available online at [http://www.qt21.eu/mqm-definition/definition-2015-12-30.html] (accessed 1 August 2020).

Orlando, Marc. 2011. 'Evaluation of translations in the training of professional translators: at the crossroads between theoretical, professional and pedagogical practices', The Interpreter and Translator Trainer, 5 (2): 293-308.

Orlando, Marc. 2012. 'Training of professional translators in Australia: process-oriented and product-oriented evaluation approaches', in Severine Hubscher-Davidson and Michal Borodo (eds), Global Trends in Translator and Interpreter Training, London: Continuum, 197-216.

Pinchin, Richard. 2015. The Productive Crime Laboratory. Releasing Time to Serve. Program Leader's Guide, UK: Forensic Knowledge Partnership.

Shreve, Gregory M. 2006. 'The deliberate practice: translation and expertise', Journal of Translation Studies, 9(1): 27-42

Shreve, Gregory M., Erik Angelone and Isabel Lacruz. 2018. 'Are expertise and translation competence the same? Psychological reality and the theoretical status of competence', in Isabel Lacruz and Riitta Jääskeläinen (eds) Innovation and Expansion in Translation Process Research, American Translators Association Scholarly Monograph Series XVIII, Amsterdam/Philadelphia: John Benjamins, 37-54.

TAUS. 2017. Quality Evaluation Using an Error Typology Approach. Available online at [https://info.taus.net/taus-error-typology-guidelines] (accessed 1 August 2020).

Way, Catherine. 2008. 'Systematic assessment of translator competence: in search of Achilles' heel', in John Kearns (ed.) Translator and Interpreter Training: Issues, Methods and Debates, London: Continuum: 88-103.

Way, Catherine. 2009. 'Bringing professional practices into translation classrooms', in Ian Kemble (ed.) The Changing Face of Translation, Portsmouth: University of Portsmouth: 131-142.

Way, Catherine. 2014. 'Structuring a legal translation course: a framework for decision-making in legal translator training', in Le Cheng, Keng Kui Sen and Anne Wagner (eds) Ashgate Handbook of Legal Translation, England, Ashgate: 135-152.

Way, Catherine. 2015. 'A Manageable Combined Assessment Approach: Competence and Decisionmaking'. Paper presented at the IATIS 5th International conference, Belo Horizonte, Brazil. Available online

at

[https://www.researchgate.net/publication/341427342_A_Manageable_Combined_Assessment _Approach_competence_and_decision-making?_sg=pmR7D8HeGMQzehJZGO4LE _PUI1 rec ZG 6qUk_hNc2rxkRd-XLMSTqKisOLGh82 _VRs9xT4hRwB11oI3tQ7Y7 PLpwYSsbl1kCK2BZFMtMS .tNGfnCdgDmI32kIJ-n2YRKoQCWg FnWd9bwxtojKOEyKGkPERtiLtdneFyQ FpEFfn 3zIduH4XV nNRa-HbuwaAvw ] (accessed 1 August 2020).

Way, Catherine. 2016. 'The challenges and opportunities of legal translation and translator training in the $21^{\text {st }}$ century', International Journal of Communication, (10): 1009-29. Available online at [https://ijoc.org/index.php/ijoc/article/view/3580] (accessed 1 August 2020). 
Way, Catherine. 2019a. 'Training and pedagogical implications', in Gary Massey, Maureen Ehrensberger-Dow and Erik Angelone (eds) The Bloomsbury Companion to Language Industry Studies, London/New York: Bloomsbury Academic Publishing, 179-207.

Way, Catherine. 2019b. 'Fostering translator competence: the importance of effective feedback and motivation for translator trainees', Intralinea. (Special Issue: New Insights into Translator Training), Available online at [http://www.intralinea.org/specials/article/2430] (accessed 1 August 2020).

Zimmerman, Barry J. 2002. 'Becoming a self-regulated learner. An overview', Theory into Practice, 41: 64-72.

\section{Annex 1}

\section{PROJECT MANAGEMENT RUBRIC}

\begin{tabular}{|c|c|c|c|c|}
\hline PROJECT MANAGER: & \multirow{2}{*}{\multicolumn{4}{|c|}{$\begin{array}{l}\text { GROUP NO.: } \\
\text { DATE: }\end{array}$}} \\
\hline \multirow[t]{2}{*}{ TRANSLATION TASK: } & & & & \\
\hline & & & & $\underset{t}{\operatorname{Suppor}}$ \\
\hline $\begin{array}{l}\text { PROFESSIONAL; Standards } \\
\text { Met Consistently / Expectations } \\
\text { Exceeded }\end{array}$ & 4 & \multicolumn{2}{|c|}{$\begin{array}{l}\text { All/Routinely/ } \\
\text { Completely }\end{array}$} & SPMiv \\
\hline $\begin{array}{l}\text { ADVANCED; Standards Met } \\
\text { Often /Some Improvement } \\
\text { Needed }\end{array}$ & 3 & \multicolumn{2}{|c|}{ Most/Mostly } & SPMiii \\
\hline $\begin{array}{l}\text { DEVELOPING; Standards Met } \\
\text { Sometimes / Considerable } \\
\text { Improvement Needed }\end{array}$ & 2 & \multicolumn{2}{|c|}{ Some/Partially } & SPMii \\
\hline $\begin{array}{l}\text { NOVICE; Standards Not Met or } \\
\text { Seldom Met/Improvement } \\
\text { Essential }\end{array}$ & 1 & \multicolumn{2}{|c|}{ Few or none/Rarely } & SPMi \\
\hline $\begin{array}{l}\text { PROJECT INITIATION } \\
\text { PM1 }\end{array}$ & 4 & 3 & 2 & 1 \\
\hline $\begin{array}{l}\text { Translation brief analysed and } \\
\text { understood }\end{array}$ & $\begin{array}{l}\text { Completel } \\
\mathbf{y}\end{array}$ & Mostly & Partially & Rarely \\
\hline $\begin{array}{l}\text { Pre-translation ST analysis/pre- } \\
\text { editing completed }\end{array}$ & $\begin{array}{l}\text { Completel } \\
\mathbf{y}\end{array}$ & Mostly & Partially & Rarely \\
\hline $\begin{array}{l}\text { Project stakeholders defined } \\
\text { (author/client/readers) }\end{array}$ & $\begin{array}{l}\text { Completel } \\
\mathbf{y}\end{array}$ & Mostly & Partially & Rarely \\
\hline $\begin{array}{l}\text { PROJECT PLANNING } \\
\text { PM2 }\end{array}$ & 4 & 3 & 2 & 1 \\
\hline $\begin{array}{l}\text { Possible problems } \\
\text { (resources/formatting/translation) } \\
\text { clearly identified and discussed } \\
\text { with relevant team member }\end{array}$ & $\begin{array}{l}\text { Completel } \\
\mathbf{y}\end{array}$ & Mostly & Partially & Rarely \\
\hline $\begin{array}{l}\text { Tasks/activities clearly outlined } \\
\text { with realistic deadlines }\end{array}$ & $\begin{array}{l}\text { Completel } \\
\mathbf{y}\end{array}$ & Mostly & Partially & Rarely \\
\hline $\begin{array}{l}\text { Project roles and responsibilities } \\
\text { clearly defined and distributed }\end{array}$ & $\begin{array}{l}\text { Completel } \\
\mathbf{y}\end{array}$ & Mostly & Partially & Rarely \\
\hline
\end{tabular}




\begin{tabular}{|c|c|c|c|c|}
\hline $\begin{array}{l}\text { PROJECT EXECUTION/TIME } \\
\text { MANAGEMENT } \\
\text { PM3 }\end{array}$ & 4 & 3 & 2 & 1 \\
\hline $\begin{array}{l}\text { Project Manager worked to make } \\
\text { team more effective throughout } \\
\text { project }\end{array}$ & Routinely & Mostly & Partially & Rarely \\
\hline Tasks/activities completed on time & Routinely & Mostly & Partially & Rarely \\
\hline $\begin{array}{l}\text { Effectively implemented } \\
\text { time/work distribution adjustments } \\
\text { when necessary }\end{array}$ & Routinely & Mostly & Partially & Rarely \\
\hline $\begin{array}{l}\text { CONTROL AND } \\
\text { MONITORING PM4 }\end{array}$ & 4 & 3 & 2 & 1 \\
\hline $\begin{array}{l}\text { Project monitoring completed at } \\
\text { each stage }\end{array}$ & Routinely & Mostly & Partially & Rarely \\
\hline $\begin{array}{l}\text { Progress reports and effective } \\
\text { feedback provided at each stage }\end{array}$ & Routinely & Mostly & Partially & Rarely \\
\hline $\begin{array}{l}\text { Issues identified and addressed } \\
\text { appropriately throughout project }\end{array}$ & Routinely & Mostly & Partially & Rarely \\
\hline $\begin{array}{l}\text { Actively looks for and suggests } \\
\text { solutions to problems. }\end{array}$ & Routinely & Mostly & Partially & Rarely \\
\hline $\begin{array}{l}\text { PROJECT CLOSURE } \\
\text { PM5 }\end{array}$ & 4 & 3 & 2 & 1 \\
\hline $\begin{array}{l}\text { All deliverables presented on time } \\
\text { or prior to deadline }\end{array}$ & All & Most & Some & $\begin{array}{l}\text { Few/ } \\
\text { None }\end{array}$ \\
\hline $\begin{array}{l}\text { Provided comprehensive analysis } \\
\text { and recommendations for } \\
\text { improvement }\end{array}$ & Routinely & Mostly & Partially & Rarely \\
\hline $\begin{array}{l}\text { Identified, evaluated, and } \\
\text { completed all requirements and } \\
\text { objectives }\end{array}$ & Routinely & Mostly & Partially & Rarely \\
\hline All deliverables clearly labelled. & Routinely & Mostly & Partially & Rarely \\
\hline
\end{tabular}

\section{Annex 2}

\begin{tabular}{|c|c|c|c|c|}
\hline $\begin{array}{l}\text { Sup } \\
\text { port }\end{array}$ & SPMiv & SPMiiii & SPMiii & SPMi \\
\hline $\begin{array}{l}\text { PM } \\
1\end{array}$ & $\begin{array}{l}\text { https://w } \\
\text { ww.inter } \\
\text { proinc.c } \\
\text { om/blog } \\
\text { /effectiv } \\
\text { e- } \\
\text { translati } \\
\text { on- } \\
\text { project- }\end{array}$ & $\begin{array}{l}\text { http://www } \\
\text { languages } \\
\text { cientific.co } \\
\text { m/9-ways- } \\
\text { a-project- } \\
\text { manager- } \\
\text { makes- }\end{array}$ & $\begin{array}{l}\text { https://www.linkedin.com/puls } \\
\text { e/main-steps-translation- } \\
\text { project-nancy-matis } \\
\text { https://courses.comet.ucar.edu/ } \\
\text { pluginfile.php/27060/mod_res } \\
\text { ource/content/12/GuideToTran }\end{array}$ & $\begin{array}{l}\text { What does a } \\
\text { translation } \\
\text { project manager } \\
\text { do? } \\
\text { http://transcripta. } \\
\text { com/translation- } \\
\text { project-manager/ }\end{array}$ \\
\hline
\end{tabular}




\begin{tabular}{|c|c|c|c|}
\hline $\begin{array}{l}\text { manage } \\
\text { ment } \\
\text { https://p } \\
\text { eschel- } \\
\text { commun } \\
\text { ications. } \\
\text { de/en/th } \\
\text { e-life- } \\
\text { of-a- } \\
\text { translati } \\
\text { on- } \\
\text { project- } \\
\text { manager } \\
\text { https://w } \\
\text { ww.proz } \\
\text { com/tra } \\
\text { nslator- } \\
\text { training/ } \\
\text { topic/tra } \\
\text { nslation- } \\
\text { project- } \\
\text { manage } \\
\text { ment }\end{array}$ & $\begin{array}{l}\text { your- } \\
\text { translation- } \\
\text { or- } \\
\text { localizatio } \\
\text { n-a- } \\
\text { success/ } \\
\text { Celia Rico } \\
\text { Translation } \\
\text { Journal } \\
\text { https://tran } \\
\text { slationjour } \\
\text { nal.net/jour } \\
\text { nal/22proje } \\
\text { ct.htm }\end{array}$ & $\begin{array}{l}\text { slationManagement_V1a_021 } \\
\text { 02017_final.pdf } \\
\text { http://www.translation-project- } \\
\text { management.com/es/tags/docu } \\
\text { mentacion-0 } \\
\text { file:///C:/Users/usuario/Downl } \\
\text { oads/screenSupp63.pdf } \\
\text { http://www.project- } \\
\text { open.com/en/tutorial- } \\
\text { translation-guide }\end{array}$ & 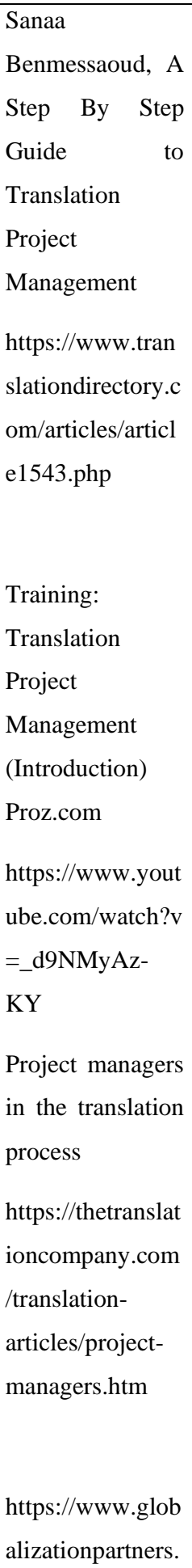 \\
\hline
\end{tabular}




\begin{tabular}{|c|c|c|c|}
\hline & & & $\begin{array}{l}\text { com/2011/03/17/ } \\
\text { why-is- } \\
\text { translation- } \\
\text { project- } \\
\text { management- } \\
\text { necessary/ }\end{array}$ \\
\hline $\begin{array}{l}\text { PM } \\
2\end{array}$ & $\begin{array}{l}\text { http://w } \\
\text { ww.tran } \\
\text { slation- } \\
\text { project- } \\
\text { manage } \\
\text { ment.co } \\
\text { m/sites/t } \\
\text { ranslatio } \\
\text { n- } \\
\text { project- } \\
\text { manage } \\
\text { ment.co } \\
\text { m/files/i } \\
\text { nline- } \\
\text { files/KS } \\
\text { ERE_R } \\
\text { MinTP.p } \\
\text { df }\end{array}$ & $\begin{array}{l}\text { Project planning for beginners } \\
\text { https://www.youtube.com/wat } \\
\text { ch?v=ZWmXi3TW1yA }\end{array}$ & $\begin{array}{l}\text { https://www.sdl.c } \\
\text { om/software- } \\
\text { and- } \\
\text { services/translati } \\
\text { on- } \\
\text { software/project- } \\
\text { management/ }\end{array}$ \\
\hline
\end{tabular}




\begin{tabular}{|c|c|c|c|c|}
\hline $\begin{array}{l}\mathbf{P M} \\
3\end{array}$ & $\begin{array}{l}\text { https://w } \\
\text { ww.sdl.c } \\
\text { om/dow } \\
\text { nload/11 } \\
\text {-tips-on- } \\
\text { effective } \\
\text {-time- } \\
\text { manage } \\
\text { ment- } \\
\text { for- } \\
\text { project- } \\
\text { manager } \\
\text { s/12557 } \\
6 /\end{array}$ & $\begin{array}{l}\text { https://onli } \\
\text { nepmcours } \\
\text { es.com/per } \\
\text { sonal-time- } \\
\text { manageme } \\
\text { nt/ }\end{array}$ & $\begin{array}{l}\text { https://www.textunited.com/bl } \\
\text { og/translation-project- } \\
\text { management-checklist/ }\end{array}$ & $\begin{array}{l}\text { https://www.ccjk } \\
\text {.com/time- } \\
\text { management-in- } \\
\text { translation/ } \\
\text { http://www.acce } \\
\text { nsus- } \\
\text { training.com/tim } \\
\text { e-management- } \\
\text { essentials/ } \\
\text { https://samedaytr } \\
\text { anslations.com/bl } \\
\text { og/the-clock-is- } \\
\text { ticking-time- } \\
\text { management-for- } \\
\text { translators/ }\end{array}$ \\
\hline $\begin{array}{l}\text { PM } \\
4\end{array}$ & $\begin{array}{l}\text { https://w } \\
\text { ww.ican } \\
\text { localize. } \\
\text { com/site } \\
\text { /2010/08 } \\
\text { /translati } \\
\text { on- } \\
\text { quality- } \\
\text { feedbac } \\
\text { k/ }\end{array}$ & $\begin{array}{l}\text { https://lead } \\
\text { ershipmana } \\
\text { gement.co } \\
\text { m.au/7- } \\
\text { essential- } \\
\text { guidelines- } \\
\text { to-giving- } \\
\text { effective- } \\
\text { feedback/ }\end{array}$ & $\begin{array}{l}\text { https://scottjeffrey.com/effecti } \\
\text { ve-feedback/ }\end{array}$ & $\begin{array}{l}\text { https://multilingu } \\
\text { al.com/eight- } \\
\text { tips-ideal- } \\
\text { translator/ }\end{array}$ \\
\hline $\begin{array}{l}\text { PM } \\
5\end{array}$ & $\begin{array}{l}\text { https://m } \\
\text { assardo. } \\
\text { com/blo } \\
\mathrm{g} / \text { checkl } \\
\text { ist- } \\
\text { translati } \\
\text { on- } \\
\text { project- }\end{array}$ & $\begin{array}{l}\text { https://ww } \\
\text { w.net- } \\
\text { translators. } \\
\text { com/blog/l } \\
\text { ocalization } \\
\text {-project- } \\
\text { handoff- } \\
\text { checklist/ }\end{array}$ & $\begin{array}{l}\text { https://www.smartsheet.com/d } \\
\text { efining-and-delivering-project- } \\
\text { deliverables }\end{array}$ & $\begin{array}{l}\text { http://www.proje } \\
\text { ct- } \\
\text { open.com/en/tuto } \\
\text { rial-translation- } \\
\text { guide\#translation } \\
\text { _project_closing } \\
\text { _invoicing }\end{array}$ \\
\hline
\end{tabular}




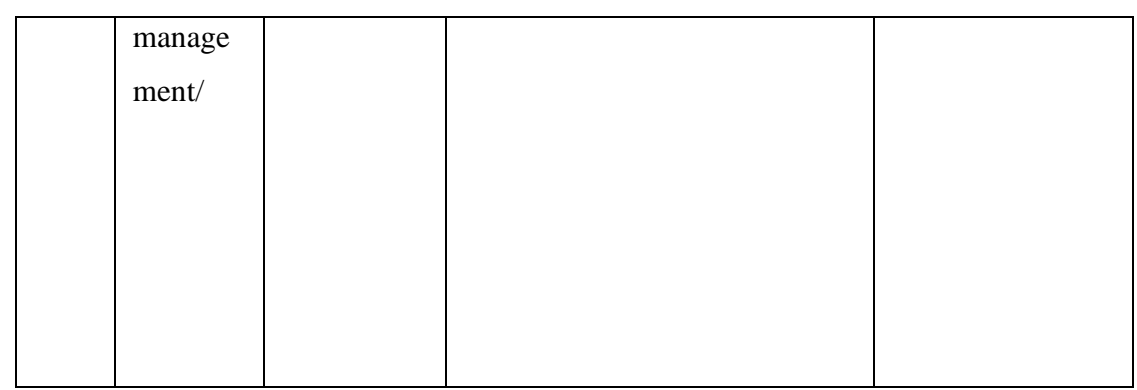

